\title{
MODERN ECONOMIC SPACE IN POLISH CITIES AS A SYMPTOM OF GLOBALISATION
}

\author{
Magdalena WdOWICKA \\ Adam Mickiewicz University, Institute of Socio-Economic Geography and Spatial Management, Poznań, \\ Poland
}

Manuscript received June 12, 2011

Revised version October 24, 2011

\begin{abstract}
Wdowicka M., Modern economic space in Polish cities as a symptom of globalisation. Quaestiones Geographicae 30(4), Bogucki Wydawnictwo Naukowe, Poznań 2011, pp. 33-38, 7 figs. DOI 10.2478/v10117-011-0035-8, ISBN 978-83-62662-88-3, ISSN 0137-477X.
\end{abstract}

AвSTRACT. Globalisation primarily embraces cities, which turn into major nodes of the global economic network. It is here that huge transnational corporations locate their operations, an intensive exchange of information takes place, and the largest global flows are registered. In seeking to adjust their economic and spatial structure to the requirements of the competitive global economy, cities undertake large-scale infrastructural investments and develop new forms of organisation of their economic space, including scientific-technological parks, high-quality spaces offering services to producers and business people, and modern office districts where the headquarters of global corporations, international economic organisations and financial institutions are concentrated. The aim of the paper is to analyse the resources of modern economic space in Polish cities in the age of dynamic globalisation, in particular such elements of this space as high-quality office stock and technological parks.

KEY WORDS: cities, globalisation, transnational corporations, office market, technological parks

Magdalena Wdowicka, Institute of Socio-Economic Geography and Spatial Management, Adam Mickiewicz University, ul. Dzięgielowa 27, 61-680 Poznań, Poland; e-mail:megan@amu.edu.pl

\section{Introduction}

The results of numerous studies carried out at the close of the 20th century and the beginning of the 21st show globalisation to embrace primarily large cities, which turn into major nodes of the global economic network (cf. Castells 1989, Friedmann 1995, Robertson 1995, Graham \& Marvin 2001, Scott 2001, Hall 2005, Sassen 2006, Czerny 2007). It is here that huge transnational corporations locate their operations, an intensive exchange of information takes place, and the largest global flows of international investment capital, advanced technologies and high-quality human capital are registered.

Cities seek to adjust their economic and spatial structure to the requirements of the competitive global economy by undertaking large-scale infrastructural investments (telecommunications, transport, communications, futuristic airports and railway stations) and developing new forms of organisation of their economic space, including technopoles (sites where research on advanced technologies is conducted), high-quality spaces offering services to producers and business people, and modern office districts where the head- 
quarters of global corporations, international economic organisations and financial institutions are concentrated (Benko 1993, Scott 1988).

The aim of the paper is to analyse the resources of modern economic space in Polish cities in the age of a dynamically globalising economy, in particular such elements of this space as highquality office stock and technological parks.

\section{Development of global functions in cities at the turn of the 21st century}

In the large cities of highly advanced states (in Western Europe, North America and Japan), it was already in the 1970s that one could observe dynamic development of their financial sectors, telecommunications functions and international cooperation at the cost of industrial functions, but with management and R\&D functions preserved. This helped them to quickly adjust their economic and spatial structures to the needs of a globalising economy (Węcławowicz 2007, Szymańska 2008). At the start of the 21st century, one can observe further deindustrialisation taking place in those cities, the development of banking and the ICT sector (information and communications technology), and a concentration of universities, research institutes and academic associations as well as cultural activity. They earmark very high investment outlays for the construction of modern office districts and the development of the modern technology sector, including the establishment and development of technopoles, which are places of concentration of scientific-technological parks, innovation research centres, hightech firms, higher schools, research institutes, and business services. In this way the cities develop global functions and undergo globalisation. The biggest producers and suppliers of information and innovation for the global economy and also world-level management and control centres are New York, London and Tokyo, highest-ranked in the hierarchy of global cities (Friedmann 1995; Sassen 2001, 2006).

Striving for a place in the global economy are also cities in developing countries, especially those in Southeast Asia that undergo rapid urbanisation. There (mostly in India) a frequent development is the formation of so-called dual cities (Pacione 2006), as in the case of Mumbai or Delhi, where multi-million slum quarters devoid of any infrastructure are located side by side with modern, spatially ordered business centres, administration and office districts, and technological centres (Bangalore) in which are seated the largest transnational corporations of the world.

The advancing globalisation of the economy, mostly under the influence of transnational corporations, has also brought a change in the spatial-functional structure of towns in countries undergoing an economic transformation, including Polish towns. For them, a chance to adjust their economic and spatial structure to the needs of the global economy quickly is large financial outlays for the development of innovation, modern technologies and physical infrastructure possible to obtain under the current (2007-2013) regional policy of the European Union.

However, taking into consideration the fact that innovative projects contribute greatly to economic growth by boosting the competitiveness and innovativeness of an economy, the results of a comparative analysis of Poland against the remaining EU states in terms of R\&D outlays are alarming. While those states expend an annual average of $1.83 \%$ of their GDP for this purpose, in Poland the figure does not exceed $0.57 \%$, and has persisted at this very low level for years. Hence a significant role in $R \& D$ funding in Poland can be played by investments located here by transnational corporations.

As has been shown by studies carried out in the recent years by international institutions (UNCTAD, Ernst \& Young, AT Kearney), Polish cities are highly attractive to transnational corporations as sites of investment, in particular R\&D centres, and to the sector of modern business services (business process outsourcing, or $\mathrm{BPO})$, especially ICT, finance and book-keeping. Poland hosts the largest number of BPO service centres of all the countries of Central and Eastern Europe, here also the largest number of jobs have been created in this sector. In 2010 there were 104 BPO centres in Polish cities (the biggest of them employing a total of more than 26.3 thous. workers) and $57 \mathrm{R} \& \mathrm{D}$ centres of foreign corporations with a staff of several thousand Polish scientists and specialists, especially in the teleinformation, 


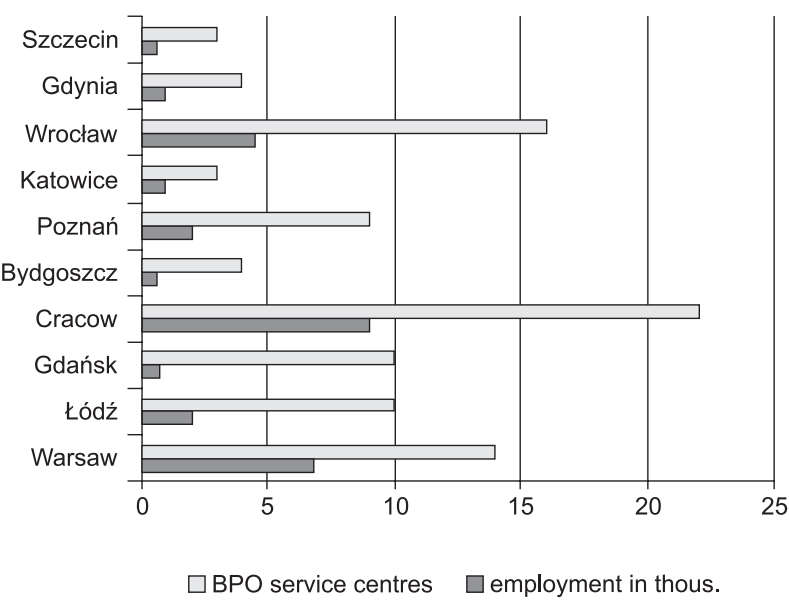

Fig. 1. BPO service centres of foreign corporations in Polish cities.

motor vehicle, chemical and aviation sectors ${ }^{1}$. Those centres are mostly located in the biggest cities with a well-developed academic hinterland. The largest number of R\&D and BPO centres have been established in Cracow, Warsaw and Wrocław (cf. Fig. 1).

\section{The office market in Polish cities and the cities of Europe and the world}

One of the most important features making Polish cities attractive to transnational corporations is the availability of high-quality office space.

In 2010, in Poland's biggest cities (Warsaw, Wrocław, Cracow, Poznań, Tri-City and Katowice) a total of more than 750 thous. $\mathrm{m}^{2}$ of modern office space were rented, while in the biggest European cities this figure was 14.8 million $\mathrm{m}^{2}$ (Knight Frank 2011b). The leader among the Polish cities in terms of office space rented was Warsaw with 549 thous. $\mathrm{m}^{2}$, which puts it high in the rank of European cities after London (1.5 million $\left.\mathrm{m}^{2}\right)$, Paris $\left(1.2\right.$ million $\left.\mathrm{m}^{2}\right)$, and Moscow (992 thous. $\mathrm{m}^{2}$ ), and before Brussels, Frankfurt, Madrid, Milan, Prague, and Amsterdam (cf. Fig. 2). Predominant among the tenants of modern office space are corporations from the financial and banking sector as well as from IT. There are further transnational corporations interested in

1 Data of the Polish Information and Foreign Investment Agency (www.paiz.gov.pl). moving their financial and book-keeping service centres to Poland as part of global cost optimisation, which may give rise to further office investment projects in major Polish cities in the nearest future.

Today the largest resources of modern office space (class A) are located in Warsaw (in excess of 2.6 million $\mathrm{m}^{2}$ ), Cracow and Wrocław (cf. Fig. 3). Office investments are located primarily in the central parts of the cities, which is facilitated by the advancing deindustrialisation of urban space. The development of office markets in the Polish biggest cities has made them interesting to a growing number of international developers.

Apart from Warsaw, which is the most mature office market in Poland, also Cracow shows high development dynamics in this field. In 2010, after two years of depressed investment dynamics on the office market in Polish cities as a consequence of the global economic crisis, one could observe clear marks of an upswing (Knight Frank 2011a). Its manifestations were both, a rising demand

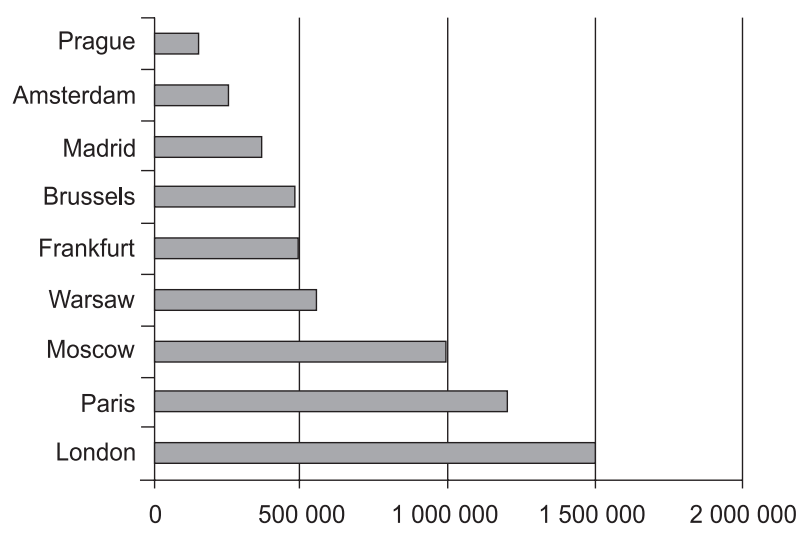

Fig. 2. Modern office space rented in selected European cities in 2010 (in $\mathrm{m}^{2}$ ).

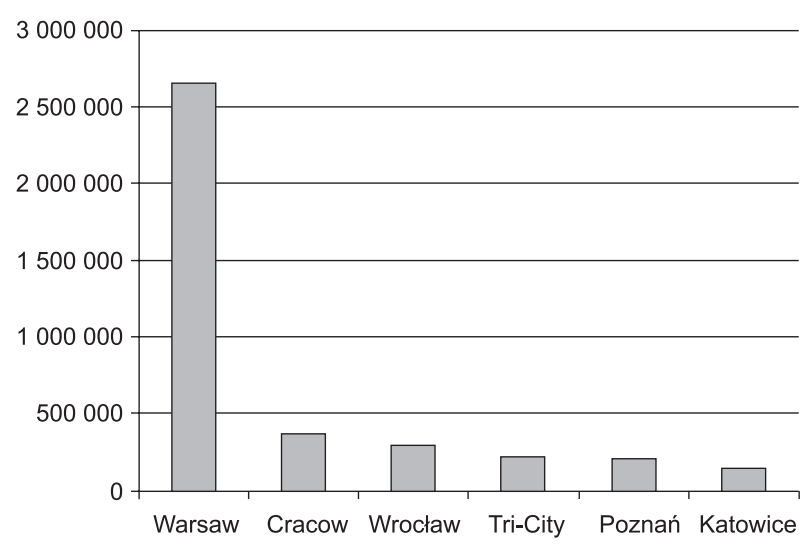

Fig. 3. Modern office stock in selected Polish cities (in $\mathrm{m}^{2}$ ). 


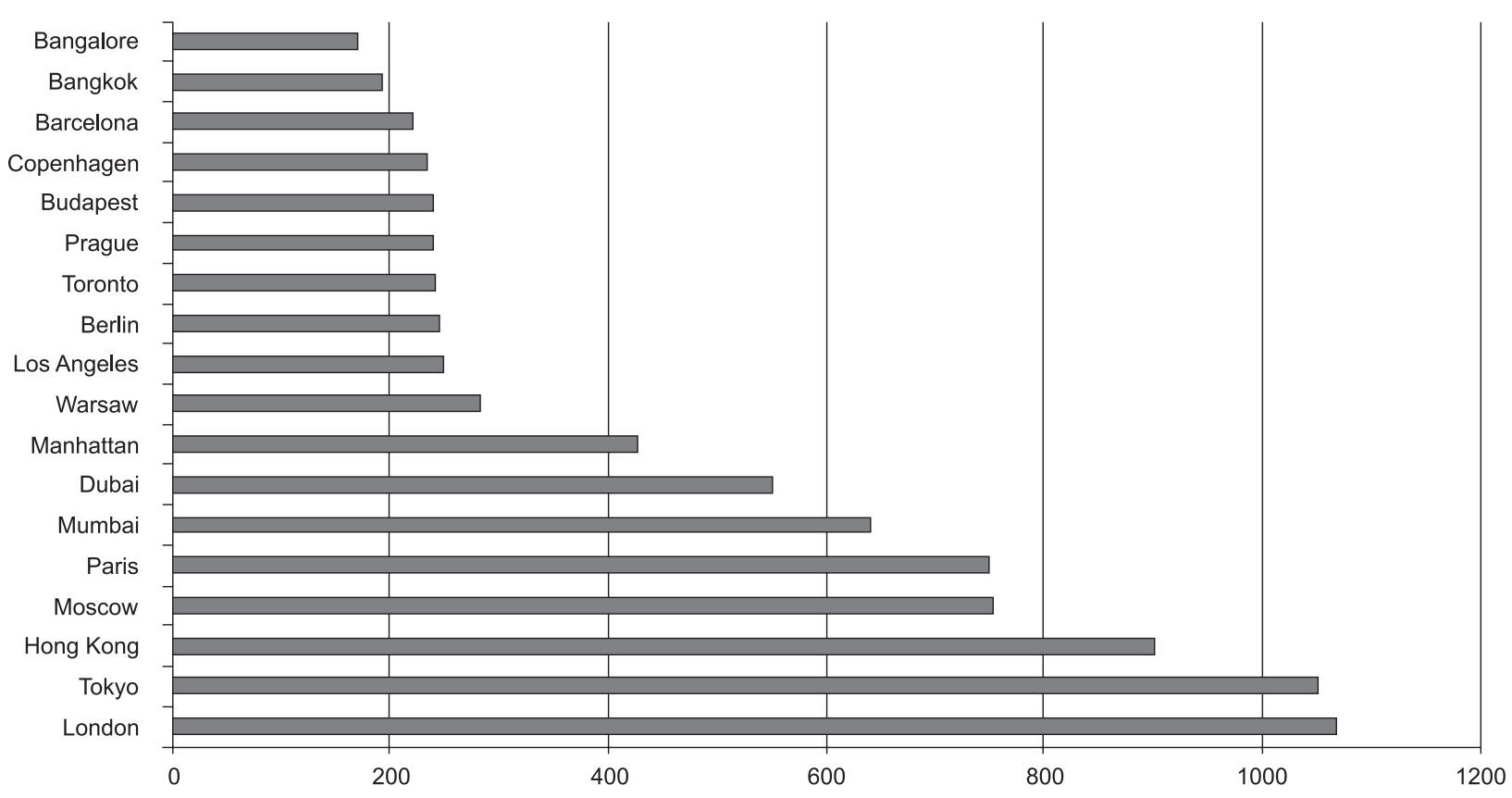

Fig. 4. Cost of rental of modern office stock in selected cities of the world in 2010 (euro/ $\mathrm{m}^{2} /$ year).

for modern office space in most of the major cities and in a steadily growing number of newly started office investments. Since the beginning of 2010, a total of about 300 thous. $\mathrm{m}^{2}$ of new offices have been completed on the six largest office markets in Poland (Warsaw, Cracow, Wrocław, Poznan, Tri-City, and Katowice), of which more than $40 \%$ are located in Warsaw. Over that time, work has started on the construction of 28 office facilities offering a total of 407 thous. $\mathrm{m}^{2}$ of highclass office space for rent (Knight Frank 2011a). Currently the largest office premises are being built in Warsaw (ca. 330 thous. $\mathrm{m}^{2}$ ) and Cracow (52 thous. $\left.\mathrm{m}^{2}\right)$, and the smallest, in Katowice (10.2 thous. $\mathrm{m}^{2}$ ).

The effects of the economic downturn observed in the previous years, when only a few investment projects were launched (in 2009 a mere 16 facilities with a total area of 89 thous. $\mathrm{m}^{2}$ started to be erected), are going to be still felt in 2011. According to the forecasts of Knight Frank, an international property agency and consultancy, in 2011 office premises on the largest office markets in Poland were to increase by a total of 196 thous. $\mathrm{m}^{2}$, some 35\% less than in 2010 and 60\% less than in 2009 (Knight Frank 2011a).

Vacancy rates in office facilities in the biggest Polish cities vary from a few to over ten percent (Knight Frank 2011a, 2011b). Warsaw has a vacancy rate $(7 \%)$ that belongs to the lowest in Eu- rope and the world (in most American and Asiatic cities this figure oscillates around $20 \%$ ).

In turn, rental values of modern office space average 17 euro $/ \mathrm{m}^{2} /$ month in Warsaw (in the best locations, $18-26.5$ euro $/ \mathrm{m}^{2}$ ), and from 14 to 17 euro $/ \mathrm{m}^{2}$ in Cracow, Wrocław, Poznań, TriCity and Katowice. The cost in Warsaw is much higher than in Los Angeles, Berlin, Toronto, Copenhagen, Prague, Bangkok, Bangalore, or Barcelona (cf. Fig. 4).

\section{Technological parks in Polish cities}

In the space of Polish cities, as in those located in other regions of the world, there appear not only modern office projects, but also a growing number of innovative structures supporting business in the age of the globalising economy. They include scientific-technological parks, technology transfer centres, and technological incubators, set up on the initiative of higher schools or local private entities. Today in Polish cities there are 26 technological parks, 47 technology transfer centres, and 16 technological incubators ${ }^{2}$. In organisational and conceptual terms, the best developed type of innovation centres in Poland

2 Data of the Polish Agency for Enterprise Development (www.pi.gov.pl). 


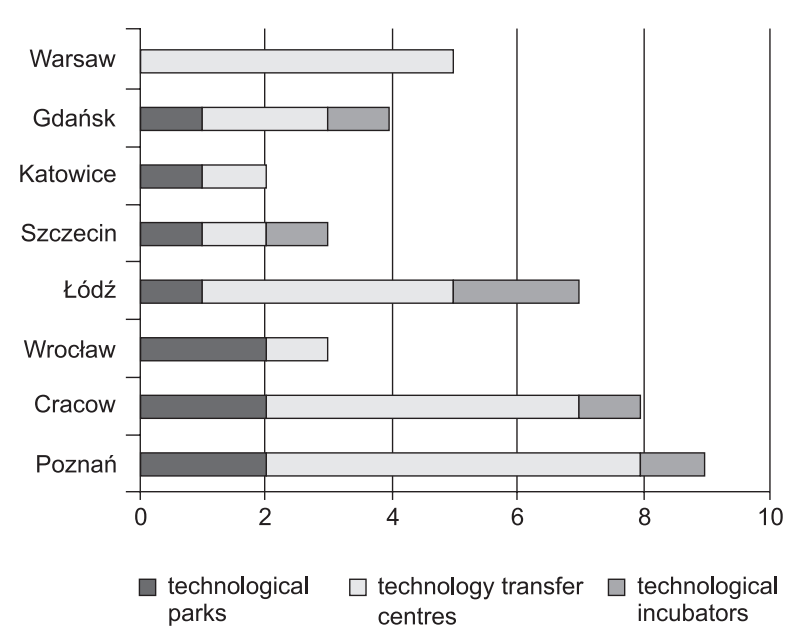

Fig. 5. Innovative institutions in selected Polish cities.

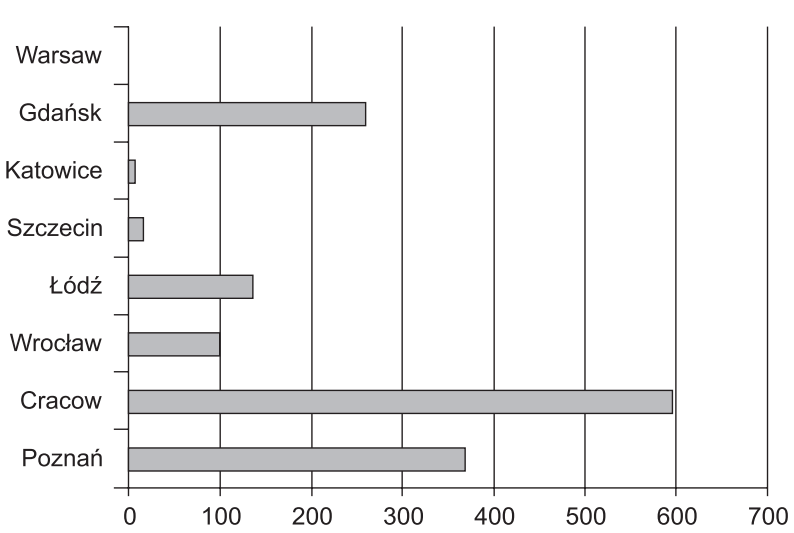

Fig. 6. Land resources in technological parks in selected Polish cities (in $\mathrm{m}^{2}$ )

are technological parks ${ }^{3}$, of which more than $76 \%$ have reached the stage of maturity (Kowalak 2010).

The greatest number of innovative institutions are located in the biggest cities (Poznań, Warsaw, Cracow, Wrocław, Łódź and Szczecin), each supported by a well-developed academic hinterland (cf. Fig. 5). In terms of area, technological parks are the largest. Decidedly the largest stock of in-

\footnotetext{
As defined by the Financial Support of Investment Act of 20 March 2002, a technological park is a complex of premises, together with physical infrastructure, specially established to enhance the flow of knowledge and technology between scientific units and entrepreneurs, in which entrepreneurs employing modern technologies are offered consultancy services concerning the establishment and development of a business, the transfer of technology, and transforming the results of R\&D work into technological innovations; also, those entrepreneurs are offered the possibility of conducting their economic activity using the premises and their physical infrastructure on the basis of a contract (Kowalak 2010: 7).
}

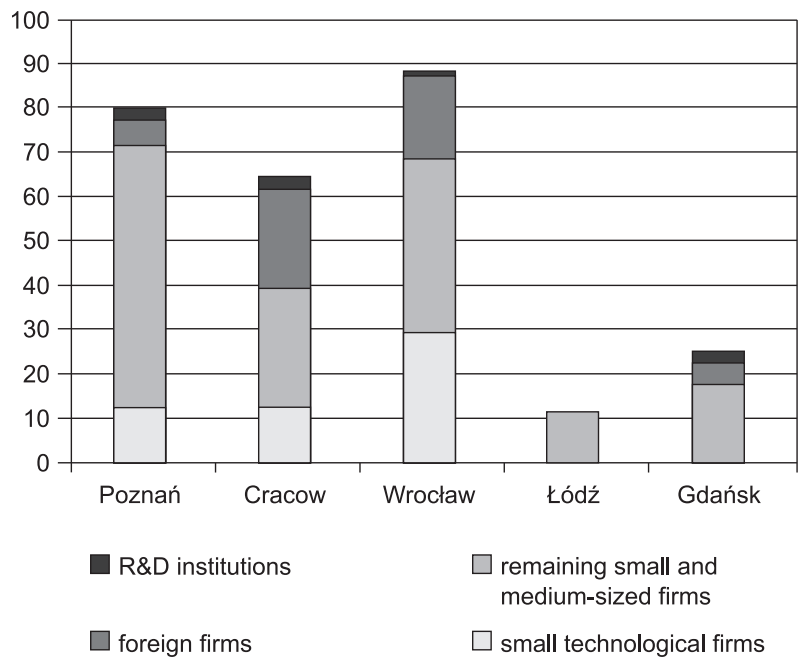

Fig. 7. Structure of technological park users in selected Polish cities.

novation space can be found in Cracow (cf. Fig. 6).

The bulk of users of technological parks are small and medium-sized firms $(66.3 \%)$ as well as small technological firms $(16.2 \%)$, while foreign firms (9.8\%) and research institutions (3.4\%) come a distant third and fourth. The make-up of technological park users in selected Polish cities is presented in Fig. 7.

\section{Summing up}

In the space of Polish cities, one can speak of steady development of global functions only in the case of the biggest ones, especially Warsaw. Located in the capital are 38 branches of the largest transnational corporations of the world and the seats of numerous international financial and insurance institutions, which proves the city to have joined the global economic system. Warsaw also shows the most dynamic development of global modern economic space among the Polish cities. It has more than 2.6 million $\mathrm{m}^{2}$ of high-class office space, while a next 330 thous. $\mathrm{m}^{2}$ are under construction. Warsaw is in the lead of European cities in terms of the volume of office space rented by global corporations, the price of office rental, and a low vacancy rate.

Also Cracow makes relatively rapid advances in the globalisation of its urban space; it is this city that boasts the greatest concentration of $R \& D$ centres and BPO service centres of transnational 
corporations among Polish cities. Cracow has also the largest stock of innovation space located in technological parks, and the second largest (after Warsaw) resources of modern office space. In the remaining Polish cities, however, the dynamics of change in their spatial and economic structures is low when compared with other cities of the world. A persistent problem of Polish cities is low outlays for R\&D, which certainly does not enhance the level of innovativeness of their economies.

\section{References}

Benko G., 1993. Geografia technopolii (Geography of technopoles). PWN, Warszawa.

Castells M., 1989. The informational city. Information technology, economic restructuring, and the urban-regional process. Basil Blackwell Publishers, Oxford.

Czerny M., 2007. Globalna fabryka (A global factory). In: Czerny M. (ed.), Globalistyka. Procesy globalne i ich lokalne konsekwencje. PWN, Warszawa: 36-51.

Friedmann J., 1995. Where we stand: A decade of world city research. In: Knox P.L. \& Taylor P.J. (eds), World cities in a world system. Cambridge University Press, Cambridge: 21-47.

Graham S. \& Marvin S., 2001. Splintering urbanism. Networked infrastructures, technological mobilities, and the urban conditions. Routledge, London-New York.
Hall P., 2005. The world's urban systems: a European perspective. Global Urban Development Magazine, 1, 1 (www. globalurban.org).

Knight Frank, 2008. Office stock in major regional cities in Poland. First quarter of 2008 (www.knightfrank.com).

Knight Frank, 2009. Poland: 2009 Commercial market (www. knightfrank.com).

Knight Frank, 2011a. Poland: 2011 commercial market (www. knightfrank.com).

Knight Frank, 2011b. Global real estate markets. Annual review and outlook (www.knightfrank.com).

Kowalak B., 2010. Benchmarking parków technologicznych w Polsce. Raport 2010 (Benchmarking technological parks in Poland. A 2010 report). Polska Agencja Rozwoju Przedsiębiorczości, Warszawa.

Pacione M., 2006. City profile: Mumbai. Cities, 23(3): 229238.

Robertson R., 1995. Globalization: Time-space and homogeneity-heterogeneity. In: Featherstone M., Lash S. \& Robertson R. (eds), Global modernities. Sage Publications, London: 25-44.

Sassen S., 2001. The global city. Princeton University Press, Princeton, New York.

Sassen S., 2006. Cities in a world economy. Pine Forge Press, Thousand Oaks.

Scott A.J., 1988. New industrial spaces. Flexible production organization and regional development in North America and Western Europe. Pion, London.

Scott A.J., 2001. Global city-regions. Trends, theory, policy. Oxford University Press, Oxford.

Szymańska D., 2008. Urbanizacja na świecie (Urbanisation in the world). PWN, Warszawa.

Węcławowicz G., 2007. Geografia społeczna miast (The social geography of cities). PWN, Warszawa. 